\title{
MDGs on Universalization of Primary Education: Analysis of Gaps Between Commitment and Implementation in Pakistan
}

\author{
Mr. Attaullah \\ Ph.D Scholar, Department of Education, Faculty of Social Sciences, International \\ Islamic University, Islamabad; Email: atta.azlan@gmail.com

\section{Dr. Samina Yasmeen Malik}

Chairperson/Associate Professor, Department of Education, Faculty of Social Sciences, International Islamic University, Islamabad; Email: samina.malik@iiu.edu.pk

\section{Doi:10.5901/mjss.2015.v6n6s1p224}

\section{Abstract}

Pakistan is a signatory to the Millennium Development Goals of the United Nations which stressed for achieving Universal Primary Education up till 2015. The deadline of the commitment has been reached but Pakistan is still far behind to achieve its targets of MDGs related to Universal Primary education. The current paper is based on document analysis which was designed to analyze the commitment made by government of Pakistan in National Education Policy-2009 for achieving MDGs targets. Ten main provisions for achieving MDGs were selected from National Education Policy -2009 and were analyzed in contrast with various official documents and report, prevailing practices of the Elementary \& Secondary Education Department as well as evaluative studies of the development partners to explore the extent to which MDGs targets have been achieved. The analysis showed that although numerous provisions were suggested in the policy documents and were incorporated in action plans of the government for its implementation but it failed to achieve the desired objective of achieving MDGs targets. The latest data indicates that Pakistan is still far away from the agreed targets committed at national and international level for universalization of primary education.

Keywords: Pakistan, universal primary education, national education policy-2009, Millennium Development Goals

\section{Introduction}

The Millennium Development Goals (MDGs) are eight international goals which were formally documented during the Millennium Summit of the United Nations in 2000 (United Nations, 2010). As stated by UNESCO (2010) this Millennium Summit took place from September 6 to September 8, 2000 at the Headquarters of the United Nations in New York City attended by all 189 United Nations member states and 23 prominent international organizations. United Nations Millennium Project (2005) revealed that it was recognized that faith in the United Nations and its charter is vital for the world to be more peaceful, prosperous. Stress was given for ensuring human dignity and equity to all people, particularly to marginalized segments of society. The United Nations Millennium Declaration was ratified during this summit wherein countries and leaders of the world agreed to achieve eight goals by the year 2015.

As stated by UNESCO (2013), out of the eight goals of MDGs, goals ii and iii are directly related with education, and the rest may be linked with education as there are strong bases to believe that education is important to achieve the remaining six MDGs. UNESCO (2015) revealed that some 58 million primary school aged children are out of school around the world, Half of which are living in conflict and crisis affected areas (UNESCO, 2014). According to another figure by UNESCO (2013), Pakistan is one among those 30 countries which are unlikely to achieve Millennium Development Goals (MDGs) on Universalization of Primary education by 2015. UNICEF (2013) pointed out that 5.4 million children in Pakistan were out of school in 2011 which indicates that Universalization of Primary Education in Pakistan is still a substantial challenge. The World Bank (2013) has described gender discrimination in Pakistan as one of the most dominant factors and hurdle in the approach of Pakistan's progress towards achieving MDGs targets for education.

Memon et al, (2010) identified various challenges and issues in the education sector of Pakistan and provided a linkage between national development and education. Literacy rate in Pakistan is very low due to numerous factors including low budgetary allocation, inefficiency in implementation and supervision of programmes and low quality of 
education. Pakistan Institute of Legislative Development and Transparency (2010) stated that although Education for All is on the top priority on government business as declared by the Government of Pakistan as a key pillar of Pakistan Poverty Reduction Strategy, but the state failed to expand educational opportunities in accordance with the rapid population growth and to girls and other excluded groups as per their commitments.

\section{Objective of the Study}

The study was designed to analyze the commitment made by Government of Pakistan at National level for achieving educational targets of Millennium Development Goals in Pakistan and trace out the gaps between, commitment and implementation in achieving these targets

\section{Research Methodology}

The document analysis approach was used for this study. Through analysis of documents, the researcher offered data for approaching into the research issue. The document analysis was important for this study since it allowed the researcher to analyze the phenomenon more consistently than interview and questionnaire due to the fact that it not only allowed triangulation but also enabled the researcher to get information that was difficult to get through questionnaire and interview. As stated by Gaborone (2006) Although social surveys, in-depth interviews and participant observation have been tried and tested, they are not the only ones available nor are they always useful. The qualitative method of document analysis was used by interpretation of the documents to give voice and meaning around the assessment topic. The relation between text and context was explored through discourse analysis. The procedure identified by Payne (2004), was followed by categorizing, interpreting and identifying the lapses in the policy documents. The quality control criteria outlined by Scott (1990) was used in handling of documents including credibility of the documents, its authenticity, representativeness that whether documents are representatives of its kinds and meaning of the documents by looking comprehensibility of the sources. The National Education Policy-2009 was selected as the primary document for analysis. The Policy-2009 was analyzed by its commitments in contrast with the National Action Plan of Accelerating Millennium Development Goals (2013-16) by the Government of Pakistan, the Education Sector Plan 2008-16 of Elementary \& Secondary Education Department, Government of Khyber Pakhtunkhwa, ongoing programme of the E\&SED, official documents and reports of the Development Partners i.e. UNESCO, UNDP, DFID, GIZ, USAID, UNICEF etc. Ten main commitments made by Government of Pakistan in the National Education Policy-2009 (NEP-2009) were selected for analysis. The selection of NEP-2009 as a source to be analyzed was based on the reality that National Education Policy-2009 is the latest policy of the Government of Pakistan which was launched since the previous policy of 1998-2010 failed to accomplish with the commitment made by Pakistan for Universalization of Primary Education (Government of Pakistan, 2009).

\section{Document Analysis of National Education Policy-2009}

\subsection{Commitment No.1: Discussion and Analysis}

It was committed in the policy document that "provinces and Area Governments shall affirm the goal of achieving universal and free primary education by 2015" (Government of Pakistan, 2009).

Pakistan is far behind in achieving the targets of Universal Primary Education by 2015. According to the Economic Survey of Pakistan 2012-13, Pakistan is unlikely to achieve the MDGs targets in all its indicators. The Net Primary Enrolment Rate (NER) during 2011-12 was 57\% against the MDGs target of 100. The completion/survival rate was recorded $49 \%$ against the $100 \%$ rate as committed in MDGs. Similarly it has been committed in MDSs that $88 \%$ overall literacy will be achieved up to 2015 but according to Pakistan Economic Survey 2012-13, the present literacy rate is 58\% with a very much slow pace of progress. Gender disparity at primary level was committed to be eliminated by 2005 as per MDGs Goal no. 3, but according to the Economic Survey of Pakistan 2012-13 GPI at national level is 0.90 even in 2012 (Government of Pakistan, 2013).

\subsection{Commitment No.2: Discussion and Analysis}

The National Education Policy-2009 determined that Plans shall be developed by the Provincial and Area Governments having intermediate enrolment targets with financial and technical estimates keeping into account the aim of equity and 
special attention for girls and vulnerable children (Government of Pakistan, 2009).

Efforts have been made by the Federal, Provincial and Area Governments with the support of Development Partners for achieving its commitment in MDGs. The latest document prepared in this connection is the National Plan of Action 2013-16 which is MDG Acceleration Framework for Achieving Universal Primary Education in Pakistan. (Government of Pakistan, 2013). According to the Plan, the total number of children (5-9 years) in the country is 21.14 million (Boys 10.99 million, Girls 10.15 million) with 6.7 million out of school children (OOSC) (Boys 2.92 million, Girls 3.77 million) which showed $68 \%$ Net Enrolment Rate (73\% for boys and $63 \%$ for girls). It has been committed that $76 \%$ of OOSC (81\% boys and $71 \%$ girls) will be enrolled during plan period 2013-16. The NER at the end of the Plan period will be reached to $91 \%$. The total MDGs Acceleration Framework (MAF) cost of KP Province during the Plan period has been estimated 22,067 million. (Government of Pakistan, 2013).

\subsection{Commitment No.3: Discussion and Analysis}

To achieve the MDGs targets of Universal Primary Education, commitment was made in NEP-2009 for endorsement of inclusive education system by inclusion of special persons in mainstream education and literacy programme (Government of Pakistan, 2009).

As an outcome of the Pakistan commitment for Universal Primary Education at international level, a series of seminars, conferences and workshops were organized during 2002-2007 which resulted into a perceptual change and the National Educational Policy 2009, for the first time incorporated Inclusive Education as a solution to discrimination particularly in terms of its access to marginalized communities. Soon after the formulation of NEP-2009, wherein a drive towards inclusive education was ready to take off, the Ministry of Education was devolved to provinces as a consequent of 18th constitutional amendment. The provincial governments failed to implement inclusive approach and this approach lost its momentum due to numerous reasons including no conceptual clarity, teachers approach in terms of competency and attitude, low educational standards of public schools, the special children's parents hesitation due to unsuitable environment of the public schools for special children (Hameed, 2011).

The United Nations Children Fund (UNICEF) has pointed out the complex nature of the education policy landscape in Pakistan. The National Policy of Special Education (1998) and the National Policy for Persons with Disabilities (2002) conferred the management and supervision of special children schools to the Ministry of Women's Development, Social Welfare, and Special Education, rather than to the Ministry of Education. The Ministry of Women Development, Special Education and Social Welfare (now devolved to provincial governments) has no role with main stream education schools but the policy does not provide any involvement of the Ministry of Education in special or inclusive education. This gap in the policies has resulted in two different machineries of implementation, each working in isolation and trying to keep up power and identity independent of the other (UNICEF, 2013).

Based on the monitoring and evaluative report of its pilot project for inclusive education in Pakistan, the United States Agency for International Development (USAID) concluded that inclusive education is possible in Pakistan if appropriate resources and support are provided. The report demonstrated the capability and willingness of primary school teachers in Pakistan for inclusive education by imparting specialized trainings to these teachers. (USAID, 2010).

\subsection{Commitment No.4: Discussion and Analysis}

In National Education Policy-2009, the Government of Pakistan and its federating units committed for the allocation of 7\% of GDP to education by 2015 with necessary ratification (Government of Pakistan, 2009).

According to UNESCO (2013) the developing countries must spent at least 4\% of their GDP on education. In the National Education Policy-2009 the Government of Pakistan admitted insufficient allocation of budget for education as the reason for not achieving Universal Primary Education. Provisions were made in the policy documents for gradual increase in education budget which was committed to be enhanced to $7 \%$ of the GDP by 2015 . Despite the fact of this enhanced commitment, the implementation status in terms of expenditure on education moves in opposite direction. Government of Pakistan (2013) revealed in Pakistan's Country Report regarding Accelerating Millennium Development Goals, expenditure on education in terms of $\%$ of GDP varied from $1.7 \%$ to $2.5 \%$. The expenditure on education enhanced from $1.7 \%$ to $2.49 \%$ in 2007-08 (during the military regime), then it started to decline again from 2008 and fell to $2 \%$ of GDP during 2011-12. While Pakistan has the second largest number of children out of school children in the world, it has continued a low level of spending on education i.e. less than $3 \%$ of GNP and reduced its spending on education from $2.6 \%$ to $2.3 \%$ of GNP over the decade (UNESCO, 2012).

Appropriateness of allocation is a major challenge as well since we failed to utilize even this small allocation $100 \%$. 
Overall rate of utilization of budgetary allocation in the country ranged from $83 \%$ to $93 \%$. At national level, about $95 \%$ of the allocated budget expenditure embrace to current budget e.g. teacher's salaries while only 5\% comprised development expenditure. For 2011-12, 93\% of the allocated budget of KP province spent in current heads while only $7 \%$ spent on development heads (Government of Pakistan, 2013). As identified by UNESCO (2013) allocation of budget for education sector is an inferior process with no determination of development priorities. According to New Framework of Economic Growth of Planning Commission we are unable to spent even 2\% of our GDP on education and are expecting progress and prosperity in the country (Government of Pakistan, 2012).

\subsection{Commitment No. 5: Discussion and Analysis}

Keeping in view the Pakistan's vulnerability to natural disasters and the militancy in the region, it was committed in NEP2009 for development and implementation of a comprehensive mechanism and well formulated plan to cope with challenges of disasters (Government of Pakistan, 2009).

According to Government of Khyber Pakhtunkhwa (2012) Pakistan is vulnerable to natural disasters which have been occurred in the shape of earthquake, floods, IDPs crisis etc. Keeping in view the disasters situation, the Government of KP, Elementary \& Secondary Education Department made a Disaster Management Plan to cope with any disaster situation. The E\&S Education Department with its enormous capacity and sufficient manpower have the capability to effectively handle the disaster situation. The Department has bodies like Boys Scout, Girl Guide along with remarkable teaching and administrative staff across the province. By right utilization of these authorities, implementation of disaster plan can be implemented effectively. According to the Disaster Management Plan, the E\&S Education Department, Government of KP, focal persons will be nominated at district level for coordination and collaboration with provincial authorities at provincial level. German Development Organization $\mathrm{GIZ}$ is helping the provincial government for imparting training to the relevant persons to deal with disaster situation in the future (UNESCO, 2012).

UNICEF (2013) stated that 757,996 population including children displaced from their homes in KP and FATA due to violence and prolong military operation of war against terror, over $50 \%$ of the displaced population is children. The displaced children were living in camps with their families with insufficient social services available to them including access to education. The data provided by the Government of KP revealed that 734 schools have been damaged by militants since 2009 in the war against terror. Children in the region are also facing direct threats e.g. the attack on 14 years old Malala Yousafzai in swat district. The report indicates that, despite of the efforts of the Government and development partners, Pakistan still is not on the way to cope with challenges of disaster situation for education (UNICEF, 2013).

Attacks on Education is the documentary report of Save the Children UK which analyzed the impact of conflict and grave violations on children's education. The report specially highlighted the story of Malala Yousafzai who was attacked by the Taliban in the War affected area of Swat in Khyber Pakhtunkhwa Province. According to the report, 995 schools have been destroyed in Federally Administered Tribal Area (FATA) and KP province due to militancy and war on terror. Acid attacks on children by the armed groups have also been reported in conflict regions of the country. It has been pointed out that militancy and the subsequent War on Terror has badly affected the progress of the country towards Universal Primary Education and children, particularly girls and other marginalized groups (Save the Children UK, 2013).

\subsection{Commitment No. 6: Discussion and Analysis}

In the Education Policy of 2009, it was decided for the promotion of education for vulnerable children that a percentage of the education budget as grant in will be allocated to charitable, non-profit educational institutions. Furthermore a more comprehensive concept of free education was introduced with the provision that all education related costs including books, stationery, school bags, transport and meals will be provided by the government to poor children. It was further committed for establishment of at least two APNA GHAR residential schools in each province for vulnerable children (Government of Pakistan, 2009).

After the inculcation of the $18^{\text {th }}$ constitutional amendment which was passed by the National Assembly of Pakistan on April 8, 2010, the concurrent list was abolished and education ministry was devolved to provinces. An important and positive provision in the $18^{\text {th }}$ constitutional amendment is the addition of article 25-A which pledges the right to free and compulsory primary education for all children aged 5-16 to be provided by the federation and its federating units. The terms free and compulsory primary education according to article $25-\mathrm{A}$ is yet to be determined by the law but such a commitment has already been made in the Education Policy 2009 wherein the free education has been taken into broader term by including all school related costs in 2009 policy. It is now the responsibility of the government to cope 
with its commitments. Above $30 \%$ of the country population live below poverty line which are less prejudiced of sending their children to school and hence massive steps as per the provision of 2009 policy for provision of free education need to be taken (Pakistan Institute of Legislative Development and Transparency, 2011).

According to UNESCO (2013) some incentive schemes have been introduced by the government with the financial support of development partners e.g. provision of free text books and incentive in the form of food items and cash for girls children enrolled in rural areas schools but the commitment made in 2009 policy for a broader concept of free education and grant in aid to charity organizations for the education of vulnerable children are not yet implemented. Aording to Khyber Pakhtunkhwa Plan of Action 2013-16, to increase access and retention in Primary Schools and also to facilitate vulnerable children in achieving primary education, $1 \%$ of the total enrolled students at primary level in Khyber Pakhtunkhwa will be provided incentives @ Rs.3000 per child per year. According to the Plan, 1.5 million children will get benefit from the scheme which will cost about Rs. 4.5 billion. Poor governance and political pressure have been recognized as out of school factors and strategic interventions has been proposed in the form of effective monitoring and supervision, launching of schemes for rewards and punishment, involvement of community in school monitoring as well as the end of political interference in schools. (Government of Pakistan, 2013).

\subsection{Commitment No. 7 Discussion and Analysis}

For ensuring good governance it was committed in NEP-2009 to establish a separate management cadre for education, with specific training and qualification requirements, The political and civil servants interventions will be abolished and education sector will be given in complete control of education managers. It was further committed that all efforts will be made for introducing good governance in education sector (Government of Pakistan, 2009).

Bad governance is one of the major cause of poor performance in education sector. This reality has been recognized in NEP-2009 wherein separation of management and teaching cadre was thoroughly supported. According to UNESCO report on Education Policy Analysis in KP, the officers of the teaching cadre cannot perform well in management positions. GIZ, DFID and other Development Partners (DPS) are providing technical and financial assistance to the E\&SE Department of KP for Policy and Planning Development. The establishment of Management Cadre did not take place as per the provision of NEP-2009. It was decided in the policy that education sector will be handed over to education officers without political and civil servants interventions but it did not happen (Government of Khyber Pakhtunkhwa, 2013).

For ensuring effective monitoring and good governance, the Elementary and Secondary Education Department of $\mathrm{KP}$ initiated to Implement Biometric Attendance Monitoring System. This Biometric system is based on GPRS/GSM and can be monitored from anywhere in the world by using computer system and smart phone. This system has not been introduced in any government department in the country. It has been decided that at first instance the biometric system will be implemented at provincial level in Secretariat and Directorate of E\&SE Department which will be extended to District Education offices at second stage and secondary schools across the province at third stage (Government of Khyber Pakhtunkhwa, 2013). According to Department for International Development (DFID) Pakistan report on Khyber Pakhtunkhwa, poor governance is the major challenge for achieving Universal Primary Education targets. The abolishing of Local Learning Coordinator (LC) posts weakened the supervision of primary schools in KP province. According to DFID, the E\&SED is a centralized decision-making body, but plays its major role as implementer rather than policy making authority and enacting governance. The District offices of E\&SED have no sufficient power in term of decisionmaking. Due to its less capacity and power and political interference in teacher's posting/transfer, the District offices are facing major challenge in implementation of the Education Sector Programme (DFID, 2011).

\subsection{Commitment No. 8: Discussion and Analysis}

The NEP-2009 recognized the involvement of community as effective tool for effective management and delivery and committed of strengthening School Management Committees (SMC) through involvement of students, teachers, educationists, parents and society (STEPS) (Government of Pakistan, 2009).

Sincere efforts have been taken so for by the E\&SED of KP by establishing Parents-Teachers Council (PTC) through election process. The establishment and strengthening of these councils have been termed as revolutionary steps by the provincial government towards community participation since these councils have been assigned the power of utilization school's fund on need basis. A series of workshops have been organized with Development Partners for further strengthening the PTCs and the revision of PTC guide took place (Government of Khyber Pakhtunkhwa, 2013).

According to DFID report 2011, PTCs in KP have been delegated administrative, and financial authority at school 
level. The role of PTCs is crucial in effectively mobilization of the community in ensuring the attendance and punctuality of students and teachers and hence it can effectively reduce the dropout rate which is a major challenge in Universalization of Primary Education. For effective Monitoring and Evaluation (M\&E) of Government Primary Schools in KP, enhanced role of community and PTC is mandatory. The DFID report identified certain weak areas of PTCs these include not involvement of PTCs in school development schemes and civil works, lack of clarity on their role and subsequent under utilization of available funds and superior role of Head Teacher's as compared to PTC's role (Department For International Development, 2011).

As stated by UNESCO (2013) the enhanced role of PTC is vital for effective school management. The Development Partners are playing effective role by delivering technical and financial assistance to E\&SED for strengthening PTC through a mutual agreement with Government of KP. Training of Parents Teachers Council is an important aspect of Canada-Ausaid, Communication for Effective Social Service Delivery Programme (CESSD) 20082015. Strengthening and Reactivation of PTC is a component of Norwegian Basic Improvement Project which is a grant of Norwegian Government with a total cost of Rs. 640.014 million. Strengthening of PTC also remained a vital component in USAID funded Programme of Rehabilitation/renovation of Schools in Malakand Division. According to UNESCO report for increasing access, the maintenance and repair of school's funds have been delegated to PTCS (UNESCO, 2013).

\subsection{Commitment No. 9: Discussion and Analysis}

Missing facilities in schools is a hurdle in Universalizatization of Primary Education which was recognized in NEP-2009 and it was entrusted that efforts shall be made for the provision of missing basic facilities in schools specially in rural areas (Government of Pakistan, 2009).

According to UNESCO (2013) Government of KP has taken initiatives for the provision of missing facilities in schools. Besides conventional approach of improving infrastructure, the focus is also on the improving quality and learning environment. According to the proposed strategy, to increase access to education, missing facilities will be provided to all deficient schools on priority basis (UNESCO, 2013). According to National Plan of Action for KP 2013-16, missing of basic facilities is a key challenge in access to schools. The provision of missing facilities is an integral part of this Action Plan (Government of Pakistan, 2013). The quality of education can be enhanced by provision of basic schools. So the commitment was made for the provision of missing facilities which prevent parents to send their children in schools. (Government of Khyber Pakhtunkhwa, 2011).

The Development Partners are fully committed for provision of basic facilities in schools through a harmonized plan with provincial government. According to the Khyber Pakhtunkhwa Annual Development Plan 2013-14, EU, DFID, Norway Government and other DPs have provided financial assistance to KP Government for construction of additional classrooms, play grounds and other basic facilities through PTCs (Government of Khyber Pakhtunkhwa, 2013).

\subsection{Commitment No. 10: Discussion and Analysis}

The role of development partners DPs was recognized in the National Education Policy-2009 and it was decided that for increasing school facilities, International Development Partners shall be invited through a well-developed plan of harmonization and coordination between partners and government agencies (Government of Pakistan, 2013).

The Government of Khyber Pakhtunkhwa seems to be fully committed for invitation of International Development Partners through a well developed plan. In this connection it signed a Memorandum of Understanding (MoU) in March 2009 through E\&SED, Finance and P\&D Departments with seven international development partners. The MoU was signed between Government of Khyber Pakhtunkhwa and its key Development Partners i.e. DFID, Germany, Canada, Netherlands Embassy, Norway, Australia and the UN. The purpose of the MoU was to streamline the donor's support in education sector by avoiding duplications and effective utilization of funds. According to the MoU, it was agreed that DPs will support the plan prepared by the E\&SED of KP. The areas of intervention of this MoU are Promotion of girls education in the form of food provision for girls, provision of free text books to all children and stipends to female students, improving governance, strengthening community and parents participation and capacity building etc (UNESCO, 2013).

According to Government of Khyber Pakhtunkhwa (2013) the Education Sector Plan 2009-2015 and Provincial Plan of Action for Khyber Pakhtunkhwa have been prepared with the consultation of Development partners. The Education Sector Reform Unit (ESRU) which is an operational wing of E\&SE Department is frequently concerned in coordination and sharing of information of reform initiation with Development Partners. The ESRU seeks the feedbacks from the Development Partners for educational reforms and actions are taken accordingly. A separate coordination wing 
has also been established in ESRU to coordinate and maintain with DPS.

\section{Conclusion}

The conclusion of the document analysis has been offered in the following table;

Table 1: Conclusion of the document analysis

\begin{tabular}{|c|c|c|}
\hline Commitment & Implementation & Unresolved Issues \\
\hline 1 MDGs by 2015 & Falling well behind target & Lack of commitment \\
\hline \begin{tabular}{|l|l|}
2 & $\begin{array}{l}\text { Making laws with intermediate } \\
\text { enrollment targets }\end{array}$ \\
\end{tabular} & $\begin{array}{l}\text { National Plan of Action has been developed by } \\
\text { provinces having intermediate targets }\end{array}$ & $\begin{array}{l}\text { Historically Pakistan has a very dispirit approach } \\
\text { of achieving its Plan targets }\end{array}$ \\
\hline \begin{tabular}{|l|l|}
3 & $\begin{array}{l}\text { endorsement of inclusive education } \\
\text { system }\end{array}$ \\
\end{tabular} & $\begin{array}{l}\text { The provincial governments failed to implement inclusive } \\
\text { approach }\end{array}$ & $\begin{array}{l}\text { The complex nature of the education policy } \\
\text { landscape in Pakistan. }\end{array}$ \\
\hline $4 \begin{array}{l}\text { allocation of } 7 \% \text { of GDP to } \\
\text { education by } 2015\end{array}$ & Not implemented & $\begin{array}{l}\text { the implementation status in terms of expenditure } \\
\text { on education moves in opposite direction. }\end{array}$ \\
\hline 5 ll $\begin{array}{l}\text { Development of well formulated } \\
\text { plan to cope with challenges of } \\
\text { disasters }\end{array}$ & $\begin{array}{l}\text { The Government of KP, Elementary \& Secondary } \\
\text { Education Department has prepared a Disaster } \\
\text { Management Plan }\end{array}$ & $\begin{array}{l}\text { despite of the efforts of the Government and } \\
\text { development partners, Pakistan still is not on the } \\
\text { way to cope with challenges of disaster situation } \\
\text { for education }\end{array}$ \\
\hline $\begin{array}{l}\text { provision of education related costs } \\
6 \text { to poor children. }\end{array}$ & $\begin{array}{l}\text { Free text books are being provided by the provincial } \\
\text { government. But other measures has not been taken so } \\
\text { far. }\end{array}$ & $\begin{array}{l}\text { The formulation of strategic position for engaging } \\
\text { private sector is not yet prepared. }\end{array}$ \\
\hline \begin{tabular}{|l|l|}
7 & $\begin{array}{l}\text { Establishment of a separate } \\
\text { management cadre for education }\end{array}$ \\
\end{tabular} & Separate Management cadre has been established & $\begin{array}{l}\text { The District offices have no sufficient power in } \\
\text { term of decision-making. }\end{array}$ \\
\hline 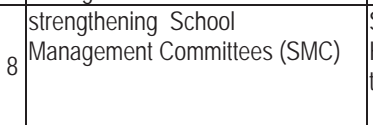 & $\begin{array}{l}\text { Sincere efforts have been taken so for by the E\&SED of } \\
\text { KP by establishing Parents-Teachers Council (PTC) } \\
\text { through election process with financial power. }\end{array}$ & $\begin{array}{l}\text { The restructuring of PTC is necessary for its } \\
\text { legitimately representative ness, transparency } \\
\text { and more representative role of PTCs than Head } \\
\text { Teachers. }\end{array}$ \\
\hline 9 provision of missing basic facilities & $\begin{array}{l}\text { initiatives have been taken for the provision of missing } \\
\text { facilities in schools }\end{array}$ & $\begin{array}{l}\text { The provision of missing facilities is an integral } \\
\text { part of Action Plan but its proper implementation } \\
\text { is a key challenge. }\end{array}$ \\
\hline $10 \begin{array}{l}\text { International Development Partners } \\
\text { shall be invited through a well- } \\
\text { developed plan }\end{array}$ & $\begin{array}{l}\text { A Memorandum of Understanding (MoU) in March } 2009 \\
\text { has been signed with international development partners }\end{array}$ & All is OK with this commitment \\
\hline
\end{tabular}

\section{References}

Department For International Development. (2005). Girls' education: towards abetter future for all retrieved from http://www2.ohchr.org/ english/issues/development/docs/girlseducation.pdf.

Gaborone, B. (2006). The use of documentary research methods in social research. African sociological review, 10(1), 221-230.

Government of Khyber Pakhtunkhwa. (2012). Education Sector Plan 2010-2015. Peshawar, Elementary \& Secondary Education Department.

Government of Pakistan (2009). The New Educational policy. Islamabad: Ministry of Education.

Government of Pakistan. (2002). National policy for persons with disabilities 2002. Islamabad: Ministry of Women Development, Social Welfare \& Special Education.

Government of Pakistan. (2013). Country Report of Pakistan Regarding Accelerating Millennium Development Goals 2013-15. Islamabad, Ministry of Education \& Training.

Government of Pakistan. (2013). National Plan of Action: Accelerating Millennium Development Goals 2013-15. Islamabad, Ministry of Education \& Training.

Government of Pakistan. (2013). National Plan of Action: Accelerating Millennium Development Goals 2013-15. Islamabad, Ministry of Education \& Training.

Government of Pakistan. (2013). Pakistan Economic Survey, 2013-14. Islamabad: Ministry of Finance, Government of Pakistan

Hameed, A. (2012). Social and economic issues of persons with disabilities in Pakistan. Retrieved from hhrd.pk/rehabnow/presentations /dr\%20abdul\%20hamid.ppt. Learning: Achieving quality for all. UNESCO, Paris

Memon, G. R., Joubish, M. F., \& Khurram, M. A. (2010). Education in Pakistan: The key issues, problems and the new challenges. Middle-East Journal of Scientific Research, 6(6), 672-7.

Pakistan Institute of Legislative Development \& Transparency. (2011). Right to free and compulsory primary education in Pakistan: enforcement of article 25-A of the constitution of Pakistan. Islamabad, pp 8-12.

Pakistan Institute of Legislative Development and Transparency. (2010). financing quality basic education in Pakistan. Islamabad, 
PILDAT.

Save the Children. (2013). Attacks On education: The impact of conflict and grave violations on children's futures. London, Save the Children UK pp 6-18.

Scott, J., 1990, A Matter of Record, Documentary Sources in Social Research, Cambridge: Polity Press.

UNESCO). (2010). Why Gender Equality in Basic Education in Pakistan? UNESCO, Islamabad.

UNESCO. ( 2015). Education for All - Global Monitoring Report - Education for All 2000-2015: Achievements and Challenges UNESCO, Paris.

UNESCO. (2012). education policy analysis report of Khyber Pakhtunkhwa. Islamabad, pp 21-67.

UNESCO. (2014). Education for All - Global Monitoring Report 2013/2014 - Teaching and

UNICEF. (2010). Thematic Paper on MDG 2: Achieves Universal Primary Education. New York, NY: UNICEF,

UNICEF. (2013). All Children in School by 2015: Global Initiative on Out-of-School Children. New York, NY: UNICEF.

UNICEF. (2013). State of the World Children: Children with Disabilities. New York, NY,

United Nations Millennium Project (2005). Towards universal primary education: investments, incentives, and institutions. London, Task Force on Education and Gender Equality.

United Nations. (2010). The Millennium Development Goals Report 2013. New York: NY, United Nations, pp 7-28, USA.

World Bank. (2013). World development indicators 2013. Washington DC, International Bank for Reconstruction and Development / The World Bank, pp-7-24. 